\title{
The UN in the Angola conflict: UNAVEM
}

$\mathrm{T}$

HE UN'S ANGOLA MISSION underwent four phases, starting with the first UN Angola Verification Mission (UNAVEM I) in 1988, through (MONUA) in $1999 .{ }^{1}$ Angola is an illuminating case, not only because it is a point of temporal comparison with the Congo and Cyprus cases, but also because the evolution of the mission itself illustrates how an ever-expanding political space was created for the UN in relation to the conflict. In this chapter, we pay particular attention to the second phase of the operation, UNAVEM II, which marked a transition from inter-state peacekeeping to intra-state peacekeeping. During this transitional period the scope and size of UNAVEM were significantly altered - a fact which is likely to shed light on possible changes in its normative basis, especially in terms of authority.

Another interesting aspect of the UN presence in Angola is the doubt that it casts on the 'evidence' of normative shift suggested by the so-called 'humanitarian interventions'. Such UN operations as the ones in Somalia, Bosnia and Rwanda are frequently taken to imply that human rights had by the early 1990s exceeded international concerns over sovereignty. Over 300,000 people died in Angola in 1993 in the presence of UNAVEM II, thus making it the second deadliest civil war (after Rwanda) between 1992 and $1996 .^{2}$ Yet the international community did not authorise a 'humanitarian intervention'. Does that mean that the tension between the norms of state sovereignty and human rights were resolved in favour of the former? It is mainly with this question in mind that we examine the UNAVEM episode.

\section{Historical background}

Angola was colonised by Portugal in 1575. In January 1975, after two decades of struggle for decolonisation, Portugal finally initiated talks for Angola's transition to independence. ${ }^{3}$ The talks at Alvor (Portugal) took place 
with the participation of three separate Angolan liberation movements: the MPLA, UNITA, and FNLA. ${ }^{4}$ The Alvor Agreement soon fell apart, and the three groups began to fight one another, with the FNLA subsequently losing its military importance. The MPLA emerged as the strongest of the three groups, and on 11 November 1975 established the People's Republic of Angola. Soviet and Cuban support for the MPLA was countered by South African and US backing for UNITA. ${ }^{5}$

Although the Angola conflict developed into a proxy war for the superpowers, it did have other dimensions, not least the ethnic divide reminiscent of both the Congo and Cyprus cases. UNITA drew its support primarily from the Ovimbundu ethnic group which made up some 40 per cent of the total Angolan population, ${ }^{6}$ while the MPLA was sometimes perceived as representing the Umbundu people which accounts for some 23 per cent of the population. $^{7}$

The situation in Namibia played a significant role in the development of the Angolan conflict. In the 1970s, South Africa was convinced that preemptive attacks on the camps of the Namibian liberation movement, the South West African Peoples' Organisation (SWAPO), inside Angola would be necessary to stop these fighters from crossing into Namibia. South African attacks were only partly directed against SWAPO. They were also aimed at capturing key points in southern Angola and consolidating UNITA as a buffer. With the so-called Total National Strategy becoming official South African policy in 1979, attacks on Angola intensified. ${ }^{8}$ By September 1980, South Africans had managed to set up UNITA headquarters in southeast Angola.

Soon after President Carter's inauguration in January 1977, the United States played an important role in constituting an informal grouping to be known as the western 'Contact Group' to deal with the complex of southern African crises. ${ }^{9}$ Reportedly, in the next few years the US Government had an ambiguous attitude to the settlement of these conflicts. Such notable figures as Cyrus Vance and Andrew Young were of the view that South Africa had to withdraw from Namibia. Otherwise, the Cuban troops would not withdraw, and an inescapable clash between Cuban and South African troops could spill over into other parts of the region, especially Rhodesia, where the United States 'would be virtually powerless to prevent immense damage to American political, economic and strategic interests' ${ }^{10}$ While the Carter administration did not at any stage accept the notion that South African withdrawal from Namibia should precede Cuban withdrawal from Angola, this line of thinking played a considerable role in the search for a diplomatic solution to the problem.

A second grouping to address these conflicts, particularly in relation to Namibia, comprised several OAU states: Angola itself, Botswana, Mozambique, Tanzania and Zambia. In 1975, the OAU had delegated its 
authority over southern Africa to these states - a formal ad hoc committee of the OAU's assembly of heads of states - whose primary aim was to contain South Africa. ${ }^{11}$ Both the Contact Group and the OAU emphasised the regional ramifications of instability in Namibia and Angola. Neither the causes nor the possible effects of such instability were considered to be primarily intra-state in nature.

\section{Towards active UN involvement}

In June-August 1977 the United States presented a settlement plan, which provided for free elections open to all Namibian political parties and the presence of a UN special representative. South Africa would begin a phased withdrawal of its troops, to be completed upon independence. The active role envisaged for the UN in settling southern African conflicts was initially spelt out in the context of the Namibian pillar of the regional problem rather than the Angolan one.

Julius Nyerere of Tanzania accepted the twin principles of elections and universal suffrage, but pointed out that the OAU's and SWAPO's main concern was that the elections should be free and fair. The answer would be to strengthen the role played by the UN which should assume legal responsibility for the territory during the transition period. UN administrative staff would need to replace the South Africans and the local authorities. According to Vance, Nyerere insisted that there should be a large UN peacekeeping force and that South Africa should be required to withdraw not part but all of its troops. ${ }^{12}$ On the day of independence SWAPO would have to take over from the UN and not from South Africa. ${ }^{13}$

The OAU approach was important in two respects: first, it explicitly accepted, even demanded, that the power vacuum in the territory be filled by the UN. No other third party was considered a suitable candidate to perform this task. Secondly, it defined the problem as an 'international' conflict, and in that sense invited the UN to perform a relatively uncontroversial task, that is, to remove the threat posed to international peace and security, which resulted from an unfinished project of decolonisation. In the meantime, Waldheim sought the agreement of Angola, Zambia and Botswana for UNTAG representatives to be established in their countries in order to facilitate the implementation of the Namibia plan. Though Angola considered a UN presence on its territory to be an infringement of its sovereignty, ${ }^{14}$ the day would come when it would consent to hosting a large UN peacekeeping mission.

In the 1980s, the Reagan administration introduced the notion of 'linkage', ${ }^{15}$ according to which the resolution of the Angola crisis would be more explicitly linked to the resolution of the Namibia question. While the notion was not at first well received by the Security Council, ${ }^{16}$ the United 
States nevertheless persisted with its attempts to get the countries concerned to negotiate a set of agreements encompassing both Namibian independence and Cuban withdrawal from Angola. By this time, South Africa had realised that it could not win a military victory in Angola, ${ }^{17}$ while the economically devastated Soviet Union had signalled its intention to halt the supply of arms to the MPLA.

\section{Addressing the international dimension}

US-mediated talks between Angola, Cuba and South Africa eventually led, on 22 December 1988 , to the signing of two agreements. ${ }^{18}$ In a tripartite agreement, the three countries undertook to commence implementation of SC Resolution 435. ${ }^{19}$ In a bilateral agreement, Angola and Cuba agreed upon a timetable for the withdrawal of the 50,000 Cuban troops from Angola. The UN Secretariat, for its part, conducted consultations with delegations from Angola and Cuba, resulting in an agreement on a set of modalities which would enable UN military observers to keep a record of Cuban troop movements. At the request of both governments, SC Resolution 626 authorised the establishment of UNAVEM on 20 December $1988 .{ }^{20}$

The UN's peacekeeping mission in Angola started, then, in traditional fashion. Like the Congo and Cyprus situations in the 1960s, the Angolan crisis was initially addressed in terms of inter-state relations. Although the conflict had obvious global, regional and domestic dimensions, the UN's prescribed role was, at first, entirely limited to the inter-state dimension of the crisis. ${ }^{21}$ In this sense, the influence of continuing Cold War constraints was all too visible.

UNAVEM's original mandate included verification of the redeployment and withdrawal of Cuban troops; ${ }^{22}$ inspection and supervision of ports, airports and bases where Cuban soldiers were deployed; and conduct of ad hoc inspections at the request of the Security Council or the UNAVEM Chief Military Observer. ${ }^{23}$ The mission, which comprised unarmed military observers, was not provided with 'rules of engagement' as the mandate did not envisage the use of force. To ensure liaison between the parties and the UN, a Joint Commission was established consisting of the Chief Military Observer as chairman, and two senior officers - one appointed by Angola and the other by Cuba.

In general, the provisions of the Angolan-Cuban agreement were complied with ${ }^{24}$ and the entire process was completed one month ahead of schedule. ${ }^{25}$ UNAVEM was based on genuine agreement between the Angolan and Cuban governments, that is, between two friendly parties and between two state parties. In Angola, at least initially, the UN did not become involved in the intra-state dimensions of the conflict. The withdrawal of the Cuban troops did not require any concession or undertaking on the side of UNITA. 


\section{Gradual transformation of the UN's role}

The origins of the Angolan conflict could not be attributed solely to the foreign presence. In January 1989 President dos Santos made an offer of peace to UNITA, which led to peace negotiations in Gbadolite (Zaire), brokered by eight African countries, on 22 June 1989. However, while dos Santos and Savimbi shook hands and signed a cease-fire agreement, within one week the parties were accusing each other of violating the cease-fire. Between April 1990 and May 1991, six rounds of negotiations between the MPLA and UNITA were convened in Lisbon, in the presence of a Portuguese mediator and US and Soviet observers.

\section{Estoril to Bicesse: no place for the UN in intra-state conflict}

These initiatives did not involve active UN participation. When it came to the intra-state dimension of the conflict, international mediation efforts were conducted largely outside the confines of the UN. At this stage, the prominent role played by Portugal, the Soviet Union and the United States was perhaps a symbolic reminder of the continuing structural influence exerted upon the conflict by decolonisation and Cold War concerns. The solution to the Angola conflict would have to reflect a particular resolution of these concerns in the light of the changing power configuration in world politics.

The first concrete example of the UN's exclusion from the peace process was the Protocol of Estoril, eventually signed by the Government and UNITA on 1 May 1991. The Protocol provided for a cease-fire to be monitored by a Joint Political-Military Commission (CCPM), composed of the MPLA and UNITA as members, and of Portuguese, Russian and US representatives as observers. According to Provision II.5, which set out the composition of the CCPM, the UN would not be an essential part of the process: 'The United Nations may be represented, in the capacity of invited guest.'

On 31 May 1991 the Government and UNITA formally signed the Bicesse Peace Accords, ${ }^{26}$ which consisted of four main documents: the Cease-fire Agreement; the Fundamental Principles; the Concepts; and the (now ratified) Protocol of Estoril. ${ }^{27}$ The UN's functions were kept to an absolute minimum. Article 4 of the Cease-fire Agreement summarised the essence of the UN's military role: 'United Nations personnel ... will verify whether the monitoring groups are assuming their responsibilities.' The Fundamental Principles and the Concepts referred to the UN only once each. While the former practically restated that the UN 'might' be invited to participate in the meetings of $\mathrm{CCPM},{ }^{28}$ Article 2 of the latter established a special link between the UN and one of the internal parties: 'The United Nations will be invited to send monitors to support the Angolan parties, at the request of the Government of Angola. ${ }^{29}$ The Government, recognised as such by the General Assembly, 
was given a privileged position, in contrast to the other provisions of the same Article, which treated both internal parties as equals: 'Overall political supervision of the cease-fire process will be the responsibility of the Angolan parties ... The Governments that are to send monitors will be chosen by the Angolan parties...'

Although politically both internal parties enjoyed the same status, the MPLA, by virtue of holding government, seemed to be primus inter pares when it came to getting the UN involved in the process legally. Here we need to recall that in practically every case of intra-state conflict, including the Congo, Cyprus and, as we shall see, Cambodia, the UN sought to deal with one 'accountable' government, which it considered the guardian of the state's sovereignty. Where government was the subject of acute contestation, including in civil war situations, the UN, as an inter-governmental organisation, much preferred to deal with a 'nominal' government until an internationally uncontested, authoritative government would emerge out of the peace process.

\section{Bicesse to UNAVEM II: a place for the UN after all}

On 17 May 1991 the Angolan Government requested UN participation in verifying the implementation of the Peace Accords. This was in effect an invitation from the host-state for the UN to become actively involved in its domestic affairs, no matter how minuscule the UN's prescribed duties would be. The Government, which once rejected an UNTAG presence in its territory on the grounds that it would violate sovereignty, came to accept the deployment of a verification mission to oversee its own domestic situation. Even though the mediators and the parties were at first not particularly keen to introduce the UN, or any other actor, into the conflict, the resolution of their differences - in interest and in viewpoint - necessitated that they make use of a suitable 'mechanism'. They also needed further legitimacy by taking into account the interests and preferences of regional powers. The UN readily suggested itself as a relatively neutral, sufficiently accountable, comprehensively multilateral and reasonably transparent option for the reconciliation of diverse positions.

On 30 May 1991, UNAVEM was given a new mandate (henceforth to be known as UNAVEM II). ${ }^{30}$ The mandate in this second phase of the Angola mission was to verify that the joint monitoring groups, composed of Government and UNITA representatives, were carrying out their responsibilities. The joint monitoring groups were to observe the cease-fire, the troops' confinement in the assembly areas, and the disarming and demobilisation of forces. ${ }^{31}$ The neutrality of the Angolan police was to be observed by monitoring teams similar in composition, and their work verified by UNAVEM II police 
observers. The role of UNAVEM II was limited to observing the monitors, and did not involve organising, regulating, or enforcing observance ${ }^{32}-$ a role described by one observer as 'watching the watchers'. ${ }^{33}$

\section{Addressing an intra-state conflict}

Gradually, the UN's active involvement in the intra-state dimension of the Angolan conflict came to be considered legitimate. During UNAVEM I and II, concern over 'respect' for sovereignty of the Angolan state was paramount. If one of the reasons for the limited observation role assigned to UNAVEM II was the failure of the Bicesse Accords to include the UN more prominently in its provisions, the other reason was that the implementation as well as direct supervision of the Angolan peace process was considered a responsibility of the Angolan people. ${ }^{34}$ In a Presidential Statement the Security Council reemphasised that 'Angola being a sovereign and independent country, the organisation and supervision of all tasks under the Peace Accords is the responsibility of the Angolan parties themselves'. ${ }^{35}$

At all stages of the mission, it was beyond dispute that the Angolan situation had clear-cut internal dimensions. At the very least, as one delegate put it, UNITA was not a foreign creation; it was and would remain an Angolan creation. ${ }^{36}$ Cuba, which was itself a state party to the southern African crises, would draw attention to two different but complementary dimensions of the situation in Angola. On the one hand, the Council was preparing to renew the mandate of UNAVEM II on the basis of the Secretary-General's report, which was primarily concerned with the internal aspects of the situation. On the other hand, the Council was meeting in response to President dos Santos' request that the issue of foreign interference in Angola's internal affairs be taken up. ${ }^{37}$ Having thus acknowledged the interplay between the internal and external issues, Cuba did not object to the UN's involvement in the conflict's intra-state dimensions. Neither did any other participant in Security Council deliberations. ${ }^{38}$

\section{Premature multi-functionalism}

On 6 February 1992, the Secretary-General appointed Margaret Anstee as his Special Representative to coordinate UN activities in connection with the Peace Accords. Given the scarce resources at her disposal, ${ }^{39}$ Margaret Anstee would compare her position with flying 'a 747 with only the fuel for a DC 3'. 40 The appointment of a Special Representative was perhaps the UN's first acknowledgment that dealing with this intra-state conflict would require substantial coordination, involving several issue areas in which the mission would have to be active. UNAVEM II's experience on the ground confirmed this, and the mission increasingly tended to go beyond mere observation of observers. 
The major problems during the attempted implementation of the peace plan were in fact of a non-military nature for both sides. Transport to remote assembly areas had proved a significant problem. Shortage of food and medicines in the assembly areas, and poor accommodation were among other reasons cited by several soldiers who revolted and ran back to their homes, depleting the number of troops in the assembly camps. ${ }^{41}$ Military personnel, who were often accompanied by their families, continually delayed mass mobilisation, citing among other reasons lack of civilian clothing..$^{42}$ UNAVEM officials and teams found that they had to play a role beyond their observation mandate: in order to play a part in the maintenance of peace and security they found it necessary to address several non-military, indeed civilian, tasks. They often took the initiative, arranged countings, organised meetings, or mediated over disputes. UNAVEM was also instrumental in getting the UN and other organisations to assist in supplying food to the assembly areas. ${ }^{43}$

Although UNAVEM II was not given the necessary authority and resources to conduct extensive field operations, none of the UN's competent organs, including the Security Council and the Secretariat, raised any objections to the relatively flexible interpretation by their field officers of UNAVEM II's mandate. Indeed, a Presidential Statement on behalf of the Security Council urged 'Member States as well as United Nations agencies to display flexibility and pragmatism' in the performance of the required tasks in the field. ${ }^{44}$

On 24 March 1992, at the request of the Government, the Security Council expanded UNAVEM II's mandate to include observation of the elections, ${ }^{45}$ without, however, making the necessary resources available. In keeping with its new mandate UNAVEM II was enlarged to include an Electoral Division. Here again the role of the UN was to observe and verify the elections, not to organise them (as would be the case in Cambodia). The expanded mission's tasks included verifying the impartiality of the electoral authorities; ensuring freedom of organisation, movement, assembly, and expression for political parties; and monitoring fair access by all political parties to State radio and television. In addition, electoral observers would monitor all activities related to the registration process, the organisation of the polls, the actual polling and the counting of the ballot. ${ }^{46}$ Although only in a monitoring capacity, the UN's Angola mission nevertheless involved promotion of political rights and civil liberties.

In a Presidential Statement the Council called on all parties 'to work closely with the Special Representative and all UN specialised agencies engaged in the electoral process to ensure that voter registration is conducted in accordance with established procedures and completed in a timely manner' ${ }^{47}$ The additional electoral role allocated to UNAVEM II was generally supported. ${ }^{48}$ UNAVEM II officials played a role beyond their 'verification/ 
monitoring' mandate in relation to their electoral mandate, too. They gave active assistance to the electoral process. Although their pragmatic attitude in the peacekeeping theatre was not specifically endorsed by the Security Council, it would enjoy considerable support from the UN membership, and attract favourable comments: 'The functions being discharged by UNAVEM II at the present time, although they do differ from those in its original mandate, are a vital factor in the peacemaking process. ${ }^{49}$ The electoral process was supported by technical assistance provided by UNDP experts and consultants. Elections were held on 29-30 September 1992, with 18 parties running for office, and 12 parties securing representation in the Parliament. Though UNITA had gained 70 seats, making it the largest opposition party, ${ }^{50}$ it did not accept the results and returned to its military campaign against the MPLA government. The Bicesse process had failed.

\section{Increasing emphasis on human rights and humanitarianism}

In late April 1993, a UN Humanitarian Assistance Coordination Unit (UCAH) was set up in Luanda to serve as the coordinating body for all humanitarian operations. It was to support the efforts of the operational UN agencies, while mobilising increased participation by other organisations. Some 50 UN agencies and NGOs conducted humanitarian operations in Angola. To cite a few examples, Médecins Sans Frontières ran a hospital in Cuito, Halo Trust engaged in de-mining, Swedrelief built bridges, and Save the Children was commissioned work by the World Food Program (WFP). ${ }^{51}$ The WFP's operation in Angola was reportedly its most complex operation and largest airlift to date. ${ }^{52}$ The organisation delivered food and other aid all over the country, flying across combat zones.

The arguments for more active humanitarian assistance and for a strengthened and expanded peacekeeping presence indicate that UNAVEM II's involvement in Angola was intended to go beyond mere observation, and beyond the performance of traditional military tasks. In 1993, the Portuguese delegate explicitly acknowledged the widening of the UN's peacekeeping agenda: 'We believe that the role of the United Nations is and will continue to be crucial not only in the search for peace but also in bringing emergency humanitarian assistance to all Angolans.' 53

While UNAVEM II's mandate recognised that the verification of democratically-held elections was the ultimate requirement for instituting peace in Angola, it did not include supervision of human rights. ${ }^{54}$ The mission's human rights activities remained limited and indirect, as exemplified by its support for a one-week human rights seminar held by the Swedish Raoul Wallenberg Institute. UNAVEM II's police contingent, tasked with monitoring the organisation, operation and neutrality of the new Angolan police force, was not equipped to perform this duty. ${ }^{55}$ Margaret Anstee would express 
regret that UNAVEM II did not have an effective human rights monitoring component. ${ }^{56}$

Britain and the United States seemed wary of UNAVEM's involvement in humanitarian and human rights issues. When UNAVEM II came physically under attack, the British held that the emphasis would have to be on the diplomatic role of the Special Representative rather than on UNAVEM II's earlier functions, which it proved incapable of fulfilling. ${ }^{57}$ Although Britain admitted that the deterioration of the human rights situation was regrettable, it did not favour an explicit link between the UN presence in the field and the 'indiscriminate killing of civilians', which 'simply [had] to stop' ${ }^{58}$ The US position was even more revealing. Madeleine Albright stated that the strength (and, by implication, the scope of functions) of UNAVEM II should not be increased until conditions were established that would make the exercise of its mandate feasible. ${ }^{59}$ In other words, for the UN to be active in such fields as humanitarian assistance, a reliable cease-fire would first need to be achieved. Here, of course, the effects of the Somalia syndrome were all too visible. ${ }^{60}$ In effect, the Anglo-American view was a restatement of a familiar normative position: first peace and security, then human rights and humanitarianism.

Notwithstanding UNAVEM II's inadequacies in mandate and resources, and the Anglo-American hesitation, there was growing normative encouragement for the UN mission to get more actively involved in humanitarian and human rights issues. The Spanish delegate's response to a report by the Secretary-General was typical in its emphasis on the importance of improving humanitarian and human rights conditions in Angola:

My delegation wishes to express its support for the emergency plan drawn up by the United Nations Humanitarian Assistance Coordination Unit in Luanda ... I must express my country's grave concern about the Secretary-General's references in his report to: 'massive human rights violations and other atrocities committed against unarmed civilians in the course of events' ${ }^{61}$

Yet it was generally the Third World countries that established a clear and insistent link between UNAVEM and provision of humanitarian and human rights assistance. The overall support given by smaller and middle powers to the enlargement and expansion of UNAVEM II highlighted the importance they gave to the UN's performance of multiple tasks, especially humanitarian assistance. ${ }^{62}$

Perhaps the sharp contrast with the US view was best expressed by the Namibian delegation which argued:

To link the extension of the mandate and enlargement of UNAVEM II to the restoration of the cease-fire is a question of the chicken and egg, and in the process, more and more Angolans will be caught in a vicious circle. Therefore, Namibia calls for a sizeable and effective United Nations presence in Angola ... ${ }^{63}$ 
Implicit in this line of thinking was the inseparability of the UN's two crucial normative objectives, that is, maintenance of peace and security and promotion of human rights and humanitarian goals. Since there was no prospect of achieving one without the other in Angola, the UN would need to pursue both objectives simultaneously. Interestingly, human rights and humanitarianism, which had been given the status of a main international concern during the mid-1970s by the persistent efforts of western (in particular US) governments, were by now adopted by a wide range of Third World countries, and imposed structural constraints on the Anglo-American position which became increasingly difficult to maintain.

\section{Creating space for judgement}

During Security Council discussions, several actors suggested that the UN's intervention in Angola was subject to both parties' consent. ${ }^{64}$ Others, however, implied that the parties' continuous consent might not be a prerequisite for the mission's viability or legitimacy. Zimbabwe advanced the argument that an increased UN presence in Angola should pursue its peacekeeping role until the objective, that is, the full implementation of the Bicesse Accords, was achieved. ${ }^{65}$ In Angola, the UN was eventually entrusted with the task of overseeing an intra-state peace agreement, regardless of how exactly that agreement came into being. That the UN did not participate in the formation of the Accords was of no consequence. Once the UN was assigned a role in settling the conflict, it should go all the way until 'peace' was achieved. By implication, peace within the boundaries of a state was considered the UN's legitimate business. This attitude, as we shall see, would be even more systematically applied in the case of Cambodia.

A significant tendency among the UN membership during the UNAVEM II episode was the perceived need to confer on the UN a referee role through its mission in the field. As a consequence, the UN's search for peace and security was now thought to depend, at least in part, on judgements as to the 'rights' and 'wrongs' of a particular conflict. Impartiality could not be taken to mean neutrality. The UN, and its extension on the ground UNAVEM, should be impartial in its evaluation of the situation, but it should not hesitate, when required, to pronounce a verdict. The Hammarskjöldian interpretation of the principle of impartiality/neutrality, as exemplified in the Congo, had been effectively abandoned. ${ }^{66}$ In the absence of the Cold War and colonial rivalries, the structural need to observe strict neutrality had evaporated.

After the elections especially, the unanimously expressed normative position of the UN was to draw a line between the 'right' party and the 'wrong' one. The Government of Angola was now considered the only legitimate authority in Angola, holding office after a 'free and fair election' endorsed by the UN. ${ }^{67}$ The more UNITA insisted on non-compliance with the 
results, the more UN members called for coercion against what they now considered the 'spoiler' party. ${ }^{68}$ Such diverse countries as Brazil, Hungary, Portugal, Russia and Zimbabwe were all calling for some form of enforcement against the party in the wrong. ${ }^{69}$ The United States, hitherto the most important supporter of UNITA, though at first unwilling to resort to sanctions, could no longer ignore the emerging normative consensus that the UN had the responsibility to pronounce on the rights and wrongs of a particular conflict. ${ }^{70}$ Eventually the United States would support the decision to impose sanctions against UNITA.

Unlike UNAVEM I, UNAVEM II is generally considered a failure. UNAVEM II's limited mandate did not match the operational objectives of the UN's involvement. In the first place, the UN was not allowed to play an active role in the negotiation process that led to the Accords. According to Margaret Anstee, 'the UN had only a very peripheral role in these negotiations so that at the end it was faced with a fait accompli'. ${ }^{71}$ In addition, the Bicesse Accords envisaged no formal role for the UN in the actual settlement of the Angolan crisis. The peace process was made entirely dependent on the adversaries, not unlike the Cyprus case or the early stages of the Congo case, where international actors were cautious about possible UN violations of sovereign rights. The UN was expected to be an impartial observer, a distant third party.

UNAVEM II marked, however, a significant transition from UNAVEM I to UNAVEM III. These latter operations were in stark contrast to each other. UNAVEM I was a small-scale observer operation, a classical exercise in interstate peacekeeping, a relatively straightforward undertaking with limited functions. UNAVEM III, which we shall briefly discuss below, was a relatively large-scale operation with an intra-state mandate and multiple functions.

\section{The Lusaka process: transformation completed}

Following the breakdown of October 1992, Margaret Anstee succeeded in arranging two rounds of talks between the two sides: in Addis Ababa and in Abidjan. In Anstee's own assessment, their ultimate failure was due to the UN's reluctance at that stage to underwrite the large international presence demanded by UNITA. ${ }^{72}$ In her view, the fundamental reason was that although the countries most closely concerned with Angola genuinely sought peace, they wanted a 'quick fix' - particularly the two superpowers whose strategic priorities had changed..$^{73} \mathrm{~A}$ third round of negotiations took place at the initiative of Anstee's successor, Alioune Blondin Beye, in Lusaka in October 1993 - one year after the resumption of fighting, and one month after the Security Council had imposed sanctions against UNITA. ${ }^{74}$ 


\section{Towards greater authority}

In Lusaka, in contrast to Bicesse, the UN maintained a central role through Beye's chairmanship. The UN authority was asserted by the threat of further sanctions against UNITA in order to bring it to the negotiating table. Conceptually, the UN's role was now expanded so as to incorporate an active element of coercion. The observation operation, UNAVEM II, was functionally 'associated' with a particular form of enforcement - sanctions - against one of the parties.

Under pressure Savimbi agreed that the basis of the negotiation would be acceptance by UNITA of the validity of the 1991 accords and of the 1992 elections. However, as the talks shifted from short-term military to longer-term political arrangements, both sides tried to gain the upper hand on the battlefield to pave the way for an advantageous final settlement. By the end of September 1994, the Security Council would declare any further obstruction or procrastination as 'unacceptable'. ${ }^{75}$ With additional pressure exerted on UNITA by the Observer States, and despite continued fighting, the Lusaka Protocol was eventually signed on 20 November 1994, and a cease-fire declared. The Protocol acknowledged the continuing legitimacy of the Bicesse Accords and of the 1992 electoral process, ${ }^{76}$ and addressed key military and political questions, as detailed in its 10 thematic annexes. ${ }^{77}$ In contrast to the Bicesse Accords, it embodied a reasonably detailed notion of national reconciliation as set out in Annex 6 with its 5 general and 18 specific principles, and 11 modalities.

Annex 8 of the Protocol, unlike the 1991 agreement, carefully laid out the precise role of the UN in the implementation process. The stark contrast with the Bicesse Accords was observable from the very beginning:

The Government and UNITA invite the United Nations to perform, in addition to its missions of good offices and mediation, the tasks defined in the present mandate with a view to the full implementation of the Acordos de Paz para Angola (Bicesse) and the Lusaka Protocol. The Observers of the peace process (the United States of America, Portugal and the Russian Federation) give their full support to this invitation. ${ }^{78}$

At first, the Observer States had been reluctant to continue negotiations through UN channels. ${ }^{79}$ However, the strong regional pressure paved the way for more direct UN involvement. As the representative of Zimbabwe put it, the Africans were 'concerned that the involvement of many negotiators [might] actually retard progress'. They therefore urged 'that discussions continue to take place under the auspices only of the United Nations and the OAU' ${ }^{80}$ In contrast to the Bicesse Accords, which were orchestrated by Angola's former colonial rulers and Cold War interventionists, that is the three Observer States, the Lusaka negotiations resulted from the efforts of Africans to solve an 
African crisis. ${ }^{81}$ Once the internal dimensions of the crisis came to the forefront, the proposed alternatives to UN mediation were no longer the Observer States, whose influence on the intra-state parties was increasingly open to question, but such African personalities as Miguel Trovoada, President of Sao Tome-Principe. ${ }^{82}$ Trovoada, however, made it known that he had no intention of replacing the United Nations as peace mediator in Angola, and that Sao Tome-Principe was completely at its disposal for whatever the UN would ask it to do. ${ }^{83}$

The persistent efforts of regional actors aside, the two internal adversaries became increasingly amenable to active UN involvement in their country partly in order to buy time (in the case of UNITA) and legitimacy (in the case of the MPLA). Although the UN had imposed sanctions on UNITA and was largely perceived as a hostile force by this party, a stronger UN presence in Angola would stabilise the military confrontation in the short term, and enable UNITA to re-organise itself in its strongholds. ${ }^{84}$ An election under UN auspices, on the other hand, would give the MPLA a much higher degree of legitimacy on the international stage, which it could then use to exert pressure on its rival. After all, for years the MPLA (in ways reminiscent of the Phnom Penh Government in Cambodia, about which more later) had been in control of the administrative apparatus which it hoped it could mobilise to win elections. Furthermore, UN sanctions and monitoring mechanisms might do precisely what the MPLA itself could not do, that is, restrict UNITA's activities. Thus it was that the UN was brought into the equation at a particular moment when the short-term interests of the internal parties overlapped with the superpowers' willingness to end a protracted 'proxy war' and with the mounting concern of African states over the regional ramifications of the conflict. The UN, it seemed, was the only strategically-placed actor which could simultaneously reconcile internal, regional, and global interests.

The UN, in the person of Blondin Beye (an African himself), was to chair the paramount institution in the implementation process: the Luanda-based Joint Commission made up of Government and UNITA nominees and Observer States' representatives. ${ }^{85}$ The UN's role was set out under four headings. The 'military issues' constituted the most detailed set of tasks assigned to the UN mission, and included 34 articles. The UN was to be directly responsible for 'overall supervision, control and verification of the cease-fire', in contrast to the vaguely defined monitoring role assigned to it in 1991. In addition, it was to have responsibility for the quartering and demobilisation of UNITA forces and reception of surrendered weapons.

The other three functions were as yet less typical for a peacekeeping operation. They related to issues which would normally be considered as falling within the domestic jurisdiction of states. Verification and monitoring of various 'police activities' constituted the second set of tasks assigned to 
UNAVEM. The UN's role in 'national reconciliation activities' involved certification that the requisite conditions for the normalisation of state administration had been fulfilled. The UN mission was charged with one other major function: to verify and monitor the successful 'completion of the electoral process'.

Although politically both the MPLA and UNITA had agreed to create a wider space for UN involvement in Angola, military hardliners on both sides were unenthusiastic about the agreement. Particularly on the Government side, military advances in 1993-94 had created an expectation of ultimate victory against UNITA. On the other side, a number of UNITA generals saw the agreement as the beginning of the end for the movement. The UN's next step in Angola was decided in this uncertain climate.

\section{Extension and expansion: consensual support for UNAVEM III}

Before, during and immediately after the Lusaka negotiations, there was a powerful temptation on the part of the UN membership to extend and expand the UN presence in Angola. Several countries were convinced that the necessary re-deployment of UNAVEM II under deteriorating conditions on the ground should not be interpreted as a lessening of the UN commitment to Angola. ${ }^{86}$ The UN presence should continue. The African countries in particular held the view that the UN's withdrawal from Angola was simply inconceivable. The overall African stance was well expressed by Namibia:

The issue at hand is ... not just the numbers themselves but a visible and effective United Nations presence ... Just two days ago, the Secretary-General of the Organization of African Unity ... appealed to the international community to give full support to the United Nations peacekeeping operations in Angola, and he further added that this was the time to strengthen the United Nations presence instead of withdrawing or reducing it, if Angola is to be prevented from sliding into a state of anarchy similar to that in Somalia. ${ }^{87}$

Indeed, African states called for a stronger and more comprehensive UN presence. ${ }^{88}$ In essence, the African position found considerable support from such extra-regional powers as Brazil, ${ }^{89}$ Hungary, ${ }^{90}$ and perhaps more importantly, the European Union (Community). ${ }^{91}$ Eventually the Observer States, too, gave their support to the extension and expansion of the UN's Angola mission, ${ }^{92}$ though US support was cautious in that the envisaged operation, no matter how much expanded, should not involve active enforcement on the ground. Referring to what would become SC Resolution 804, the US representative commented that while the United Nations was about to assume more authority and flexibility to fulfil its responsibilities, the SecretaryGeneral, UNAVEM II and concerned nations could not 'impose peace where 
the will for peace does not exist' ${ }^{93}$ The United States was not against UN coercion; it would support sanctions against one of the parties. What it opposed was coercion in the form of military enforcement.

With the deteriorating situation in the theatre of conflict, UNAVEM III was eventually authorised by SC Resolution 976 of 8 February 1995. African efforts, again crucial in the expansion of the UN's role in Angola, enjoyed the support of several middle powers. Apart from the group of African countries who had requested that they be given the opportunity to participate in Security Council deliberations leading up to the adoption of SC Resolution $976,{ }^{94}$ a number of sympathetic extra-regional governments were also involved in discussions. ${ }^{95}$ These countries pressed for an expanded UNAVEM role. ${ }^{96}$ Speaking on behalf of the OAU Council of Ministers, Malawi called for 'urgent and appropriate measures' to be taken by the UN, and urged the Security Council to facilitate the speedy establishment and deployment of an enlarged UN mission. ${ }^{97}$

UNAVEM III was given a far more comprehensive mandate than UNAVEM II. In line with the Secretary-General's recommendations, UNAVEM III involved five main components: military, political, civilian police, humanitarian and electoral. ${ }^{98}$ Perhaps as important as these five main components envisaged in the Secretary-General's report was the creation of a human rights component, directly attached to the Office of the Special Representative with various posts throughout the country. The activities of these components would be coordinated and integrated under the authority of the Special Representative. The UN's political and peacemaking activities would be performed by the Special Representative who was also in charge of a military presence. In other words, a clearer operational linkage was established in this third phase between the military and non-military functions of the UN peacekeeping mission.

The importance of such tasks as humanitarian relief and mine-clearing was expressed in numerous speeches at the Security Council. Despite the considerable expansion of its scope, however, the UN mission was still expected to perform primarily traditional military tasks, which were considered the most important step towards a political process of 'national reconciliation'. ${ }^{99} \mathrm{~A}$ fundamental flaw in the implementation of the Bicesse Accords lay in the failure to keep military disengagement and demobilisation tied to the advance of the electoral programme. As a consequence, in October 1992 UNITA was still militarily capable of returning to war following the elections. In UNAVEM III, the inter-linkage was, conceptually, more effectively maintained. The primary target of the political process, backed by the performance of military duties, was the formation of a coalition government designed to enhance national reconciliation.

In this third phase, the mission's mandate became more comprehensive 
and enjoyed consensual support. Britain, which had been sceptical of UNAVEM's assumption of multiple functions, now welcomed the SecretaryGeneral's proposal for an expansion in the human rights component of UNAVEM III. The additional human rights observers would have an important role to play in helping ensure that basic rights were respected. ${ }^{100}$

Paul Hare, the US special envoy on Angola and an active participant of the Lusaka Protocol, would claim that 'human rights was a subtext in the negotiations' in Lusaka, but that during implementation human rights had not been given the same priority as had been given to other pressing issues, such as monitoring of the cease-fire. He strongly advocated the balancing of human rights initiatives against other measures to prevent large-scale violence. Holding the two sides to human rights standards would have jeopardised delicate negotiations. ${ }^{101}$ Nonetheless, the anticipated difficulties in implementation did not prevent normative insistence on the observance of human rights, as evidenced by the inclusion of several human rights provisions in the formal agreements and operational arrangements.

Arguably, an important reason why insistence on human rights could not be dropped easily at critical moments of the Angolan negotiations was precisely the support that Washington had extended to pro-UNITA civil society campaigns throughout the 1970 s and 1980s. While providing active help for UNITA's cause against the Angolan Government in the broader context of the Cold War, such organisations as the American Security Council (ASC), the Heritage Foundation, the World Anti-Communist League and the International Society for Human Rights had frequently invoked the human rights discourse. ${ }^{102}$ They had steadily contributed, in other words, to the evolving ideational attributes of the international community. The changing political conjuncture in Angola in the 1990s was not in itself sufficient to resist the ever-stronger ideational attributes of the new era, which had been in the making for the past decades.

With hindsight, it is arguable that UNAVEM III was perhaps an even bigger failure than its predecessor, since several of its duties were not fulfilled. However, our focus here is not so much with success or failure but with the normative approach underlying the mission. In the case of UNAVEM III that approach drew on a broad-based consensus, promoted largely by the regional African states which, in the wake of a hegemonic human rights discourse, frequently appeared before the Security Council and contributed to its deliberations. Moreover, on this occasion the UN's authority in the settlement of a predominantly internal conflict was carefully based on a peace agreement signed by both intra-state parties as well as the Observer States. In the process, a special position was accorded to the UN, from which it could render judgements as to the rights and wrongs of the conflict.

With UNAVEM III, the UN got involved more clearly in the planned reso- 
lution of the Angolan civil war. An expanded UN role vis-à-vis an intra-state conflict was endorsed by the UN membership. To perform its primary duty, that is, maintenance of international peace and security, the UN began to penetrate several state functions, although not to the same extent as in Cambodia. The UN formally assumed multiple duties which would be backed by a substantial pacific military component in the field and supplementary sanctions. In June 1997, the mission entered its last phase, MONUA, ${ }^{103}$ and its mandate expired in February 1999.

\section{Concluding observations}

Although there is little evidence of a strong international will to ensure observance of human rights in Angola, the normative emphasis put on human rights and humanitarianism was now much more visible and clearly defined than before. This is not to say that the maintenance of international peace and security, understood primarily as regional stability, did not persist as the international community's chief preoccupation.

Initially, the principle of non-intervention, understood as the primary manifestation of the principle of state sovereignty, had a marked impact on the UN's role in Angola. The intra-state parties were not keen to invite UN intervention - an attitude reinforced by the unwillingness of the Observer States to involve the UN. However, the mood would gradually change for two discernible and interconnected reasons. To begin with, a settlement of the Angola conflict, long considered a major contributing factor to regional instability, became a high priority of regional states. A settlement entirely dependent on the initiative of Observer States was unlikely to take sufficiently into account, let alone reconcile, the interests and viewpoints of all relevant regional actors. Secondly, the actual on-the-ground arrangements for conflict settlement needed to reconcile simultaneously the interests of local, regional and global actors. The UN readily suggested itself as the most appropriate candidate, because it combined a number of characteristics: it had global membership, hence the capacity to accommodate the viewpoints of regional and global powers; it had a political mandate; it was able to draw on the expertise of specialised programs and agencies; and it had active field experience.

Once the UN was brought into the equation, the principle of state sovereignty gradually acquired yet a different complexion. On the one hand, the parties reduced their insistence on UN non-intervention, and on the other, the internal dimension of sovereignty gained normative priority. A second parallel trend soon emerged, namely the increasing incorporation of human rights and humanitarianism into UNAVEM's normative basis. Promotion of sovereignty in its internal dimension neatly dovetailed with the promotion of 
human rights. In other words, the tension between two crucial norms, state sovereignty and human rights, was attenuated by stressing the internal dimension of the sovereignty principle. The UN was expected to promote the creation of a political entity (stable government) which would enjoy an acceptable level of internal and external legitimacy within a defined territory. Such legitimacy would presumably depend, at least in part, on the observance of human rights.

As events unfolded, it became clear that settlement of the conflict in a way that would suit the interests of local, regional and global actors required closer and expanded UN involvement, which meant not only greater authority for the UN in all its four aspects, but also greater insistence on ensuring 'governability', as evidenced in part by the emphasis on 'national reconciliation' efforts. Aside from the expanding scope of peacekeeping functions, both in terms of depth and breadth, the increasingly generalised expectation was that the UN would no longer require the consent of all parties, that it would pronounce judgement against the party 'in the wrong', and enforce that judgement.

Interestingly, at this 'unipolar' moment, it was not the United States or its allies - as might have been expected - which drove the continuous redefinition of UNAVEM's normative basis. Without US support, no doubt, the Angola mission would not have survived. However, this support was generated through the persistent efforts of regional states and sympathetic middle powers, not to mention the indirect influence of a wide range of civil society organisations. The eventual US endorsement of sanctions against UNITA was a manifestation of this dynamic. Perhaps its most significant feature is that a coalition of actors had effectively resisted the Anglo-American preoccupation with 'peace' at the expense of 'human rights', at least at the normative level. In other words, the ideational dimension of the prevailing western hegemony imposed considerable constraints even upon the most powerful states in the system, and managed to modify their normative stance in this particular case.

\section{NOTES}

1 The estimated population of Angola in 1990 was 10,020,000: see United Nations, World Population Prospects 1990, p. 308. The ratio of UNAVEM III's largest authorised strength to the local population was 8/10,000.

2 See Stedman, International Actors and Internal Conflicts, p. 18.

3 The Angolan guerilla war for independence continued from the early 1960s until the mid-1970s. The close relationship between the liberation movements in colonial Angola and Namibia, and the corresponding close collaboration between their respective colonial powers - Portugal and South Africa - is well documented in the literature: see R. Dreyer, Namibia and Southern Africa: Regional Dynamics of Decolonization, 1945-90 (London: Kegan Paul International, 1994), especially chs 2-3.

4 Movimento Popular de Libertaçao de Angola (established in 1956, led by Agostinho 


\section{The UN, intra-state peacekeeping and normative change}

Neto), Uniao Nacional para a Independencia Total de Angola (established in 1966, led by Jonas Savimbi), and Frente Nacional de Libertaçao de Angola (established in 1962, led by Holden Roberto) respectively.

5 As late as 1990, the official US position was phrased in the following terms: 'The US will continue to support UNITA until national reconciliation, leading to free and fair elections, is achieved. The United States looks forward to normal relations with a freely elected government in Angola. Until then, we will not recognize or establish diplomatic relations with any Angolan government.' See 'Sub-Saharan Africa and US policy', US Department of State Dispatch, 1:6 (8 October 1990), 171.

6 See L. Macphisa, 'UN, US biased in Angola conflict - Terra Viva', Inter Press Service (6 December 1999), available online at www.woza.co.za/forum2/dec99/angola6.htm (9 May 2001).

7 Furthermore, while the MPLA and UNITA were the most important internal components of the Angolan conflict, there were several other Angolan groups which pursued their own military campaigns. In the oil-rich Cabinda province alone, there were at least seven factions which fought for Cabinda's 'independence': see UNHCR, Background Paper on Refugees and Asylum Seekers from Angola (Geneva, October 1994), 3.3. and 3.4.

8 See Dreyer, Namibia and Southern Africa, p. 143.

9 This group comprised the United States, Britain, and France as well as two of the elected members of the Security Council at the time, Canada and West Germany.

10 C. R. Vance, Hard Choices: Critical Years in America's Foreign Policy (New York: Simon \& Schuster, 1983), p. 274.

11 Although for different reasons, these five countries did support the efforts of the Contact Group; see Dreyer, Namibia and Southern Africa, pp. 119-22.

12 Vance, Hard Choices, p. 274.

13 Under OAU pressure, SWAPO accepted the principle of western mediation. In late March 1978, the Contact Group came up with its Proposal for a Settlement of the Namibian Situation, which would constitute the main body of SC Resolution 435 dated 29 September 1978. Eventually, both South Africa and SWAPO would accept the plan.

14 Guardian (14 August 1979) cited in Dreyer, Namibia and Southern Africa, p. 135.

15 See Dreyer, Namibia and Southern Africa, pp. 5, 145-66.

16 SC Resolution 566 of 19 June 1985 even rejected 'South Africa's insistence on linking the independence of Namibia to irrelevant and extraneous issues as compatible with resolution 435 (1978)'.

17 This not only prompted a rethinking of South African military strategy, but also gave rise to new diplomatic efforts to end the conflict: see www.hrw.org/reports/1999/ angola/Angl998-03.htm\#P439_33860 (24 May 2000).

18 For an 'official' chronology of US involvement in Angola, see N. D. Howland, 'The United States and Angola, 1974-88: a chronology', US Department of State Bulletin 89:2143 (February 1989), 16-24.

19 Though the UN's Namibia mission (UNTAG) had its roots in SC Resolution 435, it could not materialise until after the Cold War.

20 This would be followed by UNTAG's authorisation in Namibia.

21 This view was very much at the heart of the British position, which initially stressed the principle of non-intervention: 'We would welcome any move to establish internal peace which had the support of both sides, but it is not for us to prescribe how elections should be conducted in another sovereign state... The internal political situation in Angola is not the subject of discussion at the United Nations.' See the Government 


\section{The UN in the Angola conflict}

response to an inquiry in UK House of Commons, Hansard Debates, 13 March 1989, col. 25 .

22 This was set out in detail in an appendix to the bilateral agreement.

23 UNAVEM became operational on 3 January 1989.

24 The withdrawal was suspended only once, on 24 January-25 February 1990, following two attacks by UNITA against Cuban personnel during which 10 Cuban soldiers were killed.

25 It has been noted that 'as a first generation peacekeeping mission UNAVEM I was tremendously effective. It had the basic conditions outlined by Boutros Boutros-Ghali for a successful mission: a clear and practicable mandate; the cooperation of the parties; the continuing support of the Security Council, and a willingness of the Member States to contribute.' See P. Adrian, Peacemaking and Peacekeeping in Angola 1988-1994 (Geneva: Institute Universitaire des Hautes Etudes Internationales, 1994), p. 5.

26 These accords are frequently referred to in their Portuguese original: Acordos de Paz para Angola. In addition to the cease-fire, the Bicesse Accords provided for: the banning of external military assistance to the MPLA and UNITA; the confinement of all troops from both sides in assembly areas; the restoration of government administration in rebel controlled areas; the release of POWs and political prisoners; the formation of new unified 50,000 armed forces (Forças Armadas Angolanas - FAA); the disarming and demobilisation of surplus troops; the neutrality of the police force; and the holding of free and fair multi-party elections in September-November 1992. In accordance with the peace accords the following three main commissions were established beside the CCPM: a Joint Verification and Monitoring Mission (CMVF); a Joint Commission on the Formation of the Angolan Armed Forces (CCFA); and a Political Commission. In addition, several working groups were set up to deal with demobilisation, de-mining, police, humanitarian aid and other matters.

27 The full titles, respectively, are: the Cease-fire Agreement; the Fundamental Principles for the Establishment of Peace in Angola; the Concepts for Resolving the Issues Still Pending between the Government of the People's Republic of Angola and UNITA; and the Protocol of Estoril.

28 Article 2 in the document's Annex.

29 Article 4.

30 SC Resolution 696. Algeria, Argentina, Brazil, Canada, Congo, Czechoslovakia, Egypt, Guinea-Bissau, Hungary, India, Ireland, Jordan, Malaysia, Morocco, Netherlands, New Zealand, Nigeria, Norway, Senegal, Singapore, Spain, Sweden, Yugoslavia and Zimbabwe contributed to UNAVEM II: see 'UNAVEM II created to verify peaceful transition', UN Chronicle, 28:3 (September 1991), 28.

31 The process of demobilisation consisted of 4 components: assembly of troops; disarmament; demobilisation of troops not joining the FAA; and the formation of the FAA. None of these tasks would be properly accomplished. And the failure to demobilise the MPLA and UNITA forces before the elections would facilitate the return to civil war. UNAVEM II, with its inadequate mandate and resources, was unable to prevent the situation from deteriorating.

32 UNAVEM II's initial strength was 350 unarmed military observers and 89 police observers provided by 24 countries. Military observers were deployed around the country at 46 assembly points as well as such critical points as ports, airports and border posts. Police observers were also deployed in all 18 provinces. The country was divided into 6 regions; the regional headquarters were located in Luanda, Huambo, Suarimo, Luena, Lubango and Mavinga with the main UNAVEM II Headquarters in Luanda. 
33 Adrian, Peacemaking and Peacekeeping in Angola, p. 5.

$34 \mathrm{~S} / 24145$ of 24 June 1992.

35 S/PV.3092 of 7 July 1992, p. 3.

36 See Zaire's speech in S/PV.3168 of 29 January 1993, p. 117.

37 S/PV.3168 of 29 January 1993, p. 81.

38 Cape Verde, for instance, highlighted the importance of the UN assisting the establishment of a multiparty democracy in Angola; see S/PV.3062 of 24 March 1992, p. 7.

39 'In January 1993 the annual cost of UNAVEM II was roughly estimated to be US\$39 million. By contrast, UNTAG in Namibia (with only one-eighth of Angola's population) was provided with a wider mandate and a budget of US $\$ 430$ million for a period of one year and some 7,150 officials. The UN mission in Mozambique, likewise, was allocated 7,500 UN observers': see V. Krška, 'Peacekeeping in Angola (UNAVEM I and II)', International Peacekeeping, 4:1 (Spring 1997), 94.

40 Financial Times (London), 11 May 1992. This was a play on words - a reference to SC Resolution 747 expanding the mandate: see www.hrw.org/reports/1999/angola/ Ang1998-10.htm\#P1843_375081 (24 May 2000).

41 See Krška, 'Peacekeeping in Angola', p. 87.

42 See Krška, 'Peacekeeping in Angola', p. 87.

43 See Krška, 'Peacekeeping in Angola', p. 87.

44 S/PV.3092 of 7 July 1992, p. 6.

45 SC Resolution 747 was adopted unanimously.

46 UN Press Release SC/5387 of 24 March 1992.

47 S/PV.3092 of 7 July 1992, pp. 4-5.

48 See, for instance, the strong French support expressed in S/PV.3062 of 24 March 1992, p. 12. Though the United States welcomed this role, its rhetoric alluded to its unwillingness to see the elections as the UN's 'responsibility' that would be need to be carried out at all costs. The responsibility for elections should rest with the Angolans; see S/PV.3062 of 24 March 1992, p. 10. Belgium exhibited a similar attitude, stressing that the UN had intervened in Angola 'only at the explicit request of the parties' who committed themselves to the holding of free, fair and multiparty elections: see S/PV.3062 of 24 March 1992, p. 13.

49 See the speech by the Spanish delegate in S/PV.3168 of 29 January 1993, p. 54.

50 See Angola's speech in S/PV.3168 of 29 January 1993, p. 7.

51 See M. Sayagues, 'A little breathing space', Africa Report, 40:3 (May-June 1995), $14-17$.

52 See Africa Information Afrique (Harare, 18 May 1994), available online at ftp://csf.colorado.edu/ipe/Thematic_Archive/newsletters/africa_information_afrique _net/Angola/940512.ang.The_Legacy_of_War (30 May 2000).

53 S/PV.3226 of 1 June 1993, p. 16; for Guinea-Bissau's appeal to UNHCR and NGOs, see S/PV.3168 of 29 January 1993, p. 106.

54 See Y. C. Lodico, 'A peace that fell apart: the United Nations and the war in Angola', in Durch (ed.), UN Peacekeeping, American Politics, and the Uncivil Wars of the 1990s, pp. $123-4$.

55 Actually UNAVEM II's police themselves lacked training in human rights; Lodico, 'A peace that fell apart', p. 124.

56 Interview with Margaret Anstee (11 March 1998) cited in Human Rights Watch, Angola Unravels: The Rise and Fall of the Lusaka Peace Process, available online at www.hrw.org/reports/1999/angola/index.htm\#TopOfPage (30 May 2000).

57 S/PV.3168 of 29 January 1993, pp. 49-50.

58 S/PV.3168 of 29 January 1993, p. 51. 
59 Furthermore, Albright argued that before agreeing to additional commitments the United States also needed to have the Secretariat's clear advice on the costs involved and their duration; see S/PV.3254 of 15 July 1993, p. 114.

60 See, for instance, I. Ros-Lehtinen, 'Review of Clinton Administration's Performance in Africa' (Statement before the Subcommittee on Africa of the House Committee on International Relations; 26 September 1996).

61 S/PV.3226 of 1 June 1993, p. 31.

62 For Brazil's views see S/PV.3182 of 12 March 1993, p. 6 and S/PV.3206 of 30 April 1993, p. 3; for Cape Verde's views see S/PV.3226 of 1 June 1993, p. 23.

63 S/PV.3254 of 15 July 1993, p. 41.

64 Belgium, for instance, held the view that 'it must be clear that the United Nations is intervening in Angola only at the explicit request of the parties and in a precise context, namely, that of the "Acordos de Paz".' See S/PV.3062 of 24 March 1992, p. 13.

65 S/PV.3168 of 29 January 1993, pp. 88-90.

66 This normative change did, of course, attract some resistance or at least scepticism. See, for instance, Cuba's views in S/PV.3168 of 29 January 1993, pp. 83-4.

67 See, for instance, the views expressed by Mozambique, Namibia and Venezuela in S/PV.3254 of 15 July 1993 and S/PV.3168 of 29 January 1993.

68 Borrowed from S. J. Stedman, 'Spoiler problems in peace processes', International Security, 22:2 (Fall 1997).

69 For the views of these members, see S/PV.3130 of 30 October 1992, p. 9; S/PV.3182 of 12 March 1993, p. 19; S/PV.3226 of 1 June 1993, p. 16; S/PV.3182 of 12 March 1993, p. 11 and S/PV.3226 of 1 June 1993, p. 27; and S/PV.3254 of 15 July 1993, p. 21 respectively.

70 The United States was 'deeply concerned by the reports that UNITA [was] trying to extend its authority over parts of Angolan territory. If true, this would represent a major breach of the Peace Accords, which [the US] would condemn': see S/PV.3130 of 30 October 1992, p. 19.

71 M. Anstee, 'Angola: The forgotten tragedy, a test case for UN peacekeeping', International Relations, 11:6 (December 1993), 496. In her assessment of UNAVEM II in implementing the Bicesse process, Anstee insisted that 'the UN should never become involved in monitoring any peace accord where it has not taken part in negotiations ... it must have a say in drawing up its own role.' See M. Anstee, 'Angola: a tragedy not to be forgotten', The World Today, 52:7 (July 1996), 190-1.

72 Anstee, 'Angola: a tragedy not to be forgotten', 190. One reason for this caution was the apprehension that UNITA sought a large UN intervention as a means of containing FAA advances while it regrouped its own forces.

73 M. Anstee, Orphan of the Cold War: The Inside Story of the Collapse of the Angola Peace Process, 1992-93 (London: St. Martin's Press, 1996), p. 533.

74 By SC Resolution 864 of 15 September 1993 (adopted unanimously) all states were required to refrain from the supply of arms and oil to Angola 'other than through named points of entry on a list to be supplied by the Government of Angola'.

75 SC Resolution 945 of 29 September 1994 was adopted unanimously.

76 See the Protocol's Annex 2 'Re-Affirmation of the Acceptance, by the Government and UNITA, of the Relevant Legal Instruments'.

77 The political settlement differed significantly from Bicesse's winner-take-all arrangement. It committed the parties to a 'power-sharing' arrangement through the formation of a Government of Unity and National Reconciliation (GURN). The 70 UNITA deputies elected to the legislature in the 1992 election would take their seats, 


\section{The UN, intra-state peacekeeping and normative change}

and the presidential election would be completed. UNITA would appoint four ministers and seven deputy ministers. It would hold several offices at the provincial level as well.

78 Article 3 under 'I. General Principles'.

79 The Portuguese statement at the Security Council is a case in point: 'The role of the United Nations is crucial ... But the efforts of the United Nations must be accompanied by those countries with responsibilities in the process, namely the three observers ... we therefore consider that their continued involvement in the process is essential.' See S/PV.3168 of 29 January 1993, p. 98.

80 See S/PV.3254 of 15 July 1993, p. 23.

81 Lodico, 'A peace that fell apart', p. 122.

82 Trovoada was considered the only African president on good terms with both Savimbi and dos Santos.

83 Mario Dujisin/AIA/IPS (Lisbon, 27 October 1993), available online at ftp://csf.colorado.edu/ipe/Thematic_Archive/newsletters/africa_information_afrique _net/Angola/931019.Ang.Arms_From_Zaire (30 May 2000).

84 See Africa Confidential (18 February 1994) cited in UNHCR, Background Paper, 2.2.

85 Article 5 under 'I. General Principles'.

86 See, for instance, the views expressed by Cape Verde in S/PV.3226 of 1 June 1993, p. 22, and by Cuba and New Zealand in S/PV.3168 of 29 January 1993, p. 82 and p. 33 respectively.

87 S/PV.3168 of 29 January 1993, pp. 77-8.

88 See the views of Djibouti, Nigeria and Zimbabwe in S/PV.3168 of 29 January 1993. For Zimbabwe, see also S/PV.3254 of 15 July 1993, p. 22.

89 S/PV.3168 of 29 January 1993, pp. 24-5 and S/PV.3226 of 1 June 1993, p. 19.

90 S/PV.3182 of 12 March 1993, p. 19.

91 See the Spanish speech in S/PV.3168 of 29 January 1993, p. 54.

92 See, for instance, the Portuguese views in S/PV.3130 of 30 October 1992, p. 6 and S/PV.3168 of 29 January 1993, p. 101.

93 S/PV.3168 of 29 January 1993, p. 47.

94 Algeria, Guinea-Bissau, Kenya, Lesotho, Malawi, Mozambique, Namibia, Senegal, South Africa, Tunisia, Tanzania, Zaire, Zambia and Zimbabwe.

95 Brazil, India, the Netherlands, Norway, Spain and Sweden.

96 See S/PV.3499 of 8 February 1995 in its entirety.

97 S/PV.3499 of 8 February 1995, p. 6.

98 In addition to the Special Representative, the mission's organisational structure included a Deputy Special Representative, a Director for Political Affairs who would head the political component, and a legal staff.

99 See, for instance, the French statement in S/PV.3628 of 6 February 1996, p. 12.

100 S/PV.3562 of 7 August 1995, p. 12.

101 Ambassador Paul Hare cited in 'Panel 2: Angola post-Cold War harvest, panel summary', How Can Human Rights Be Better Integrated into Peace Process?: Conference Report (Washington DC: The Fund For Peace, January 1998).

102 For a survey, see A. Conchiglia, UNITA, Myth and Reality, trans M. Holness (London: ECASAAMA, 1990), pp. 54-79.

103 The United Nations Observer Mission to Angola comprised 1,500 'rapid reaction troops' to assist 345 civilian police and 85 military observers. 